\title{
Development and Thermal Characteristics of Maize- Husk Filled Polymer Composite
}

\author{
Shailesh Verma ${ }^{1}$, Anand Shukla ${ }^{2}$ \\ ${ }^{1,2}$ Vindhya Institute of Technology Jabalpur, India
}

\begin{abstract}
Maize husk is a by-product of maize milling process that usually finds inadequate final disposal (burning, land filling). Composites filled with maize husk flour are materials that offer an alternative for using this agricultural resource viewing the production of low dense materials with some specific properties. In this study, we isolated and characterized maize husk, an agricultural waste that is often left untreated and underutilized after harvest season. Moreover, we investigated the reinforcing effect of maize husk to epoxy-based bio-composite. This thesis is mainly concern with the study of favourable physical, micro-structural and thermal properties of maize husk particulate in thermosetting matrix composite.
\end{abstract}

Keywords: Maize-Husk, epoxy composites

\section{Introduction}

Composites are made up of individual materials referred to as constituent materials. There are two categories of constituent materials in composite: matrix and reinforcement. At least one portion of each type is required to make a composite. The matrix material surrounds and supports the reinforcement materials by maintaining their relative positions. The reinforcements impart their special mechanical and physical properties to enhance the matrix properties. A synergism produces material properties unavailable from the individual constituent materials, while the wide variety of matrix and strengthening materials allows the designer of the product or structure to choose an optimum combination.

\section{Literature Review}

Various kinds of polymers and polymer matrix composites reinforced with metal particles have a wide range of industrial applications such as heaters, electrodes [6]. Similarly, ceramic filled polymer composites have also been the subject of extensive research in last two decades. When silica particles are added into a polymer matrix, they play an important role in improving electrical, mechanical and thermal properties of the composites [7]. The mechanical properties of particulate filled polymer composites depend strongly on the particle size, particle-matrix interface adhesion and particle loading. Smaller particle size yields higher fracture toughness for calcium carbonate filled high density polyethylene (HDPE) [8]. Thus, particle size is being reduced rapidly and many recent studies have focused on how single-particle size affects mechanical properties [9-10]. Nakamura et al. [11-12] discussed the effects of size and shape of silica particle on the strength and fracture toughness based on particle-matrix adhesion and also found an increase in the flexural and tensile strength as specific surface area of particles increased. Usually the strength of a composite strongly depends on the stress transfer between the particles and the matrix [13]. For well-bonded particles, the applied stress can be effectively transferred to the particles from the matrix resulting in an improvement in the strength. However, for poorly bonded micro particles, reduction in strength is found to have occurred. Nicolais and Nicodemo [14] studied the effect of particle shape on tensile properties of glassy thermoplastic composites.

\section{Fabrication \& Preparation of Composite Slabs}

The maize husks were collected locally. They were washed several times with plain water to remove the dust and other foreign particles adherence to the fibers and were dried in sun light. Then these Maize husk fibers sieved with sieve shaker and a particular size (i.e. $10 \mathrm{~mm}$ ) maize husk fiber is chosen for the experiment. Usual hand lay-up technique was used for preparation of the samples. A plastic mold was used for casting the composite sheet. A mold release spray was applied at the inner surface of the mold for quick and easy release of the composite sheet. For different weight fraction of fibers, a calculated amount of epoxy resin and hardener (ratio of 10:1 by weight) was thoroughly mixed in a glass jar and placed in a vacuum chamber to remove air bubbles that got introduced. Then calculated amount of maize husk is added to the mixture of epoxy resin and hardener and mixed properly. Then the composite mixture is poured in to the mold.

Table 1: List of Particulate Filled Composites Fabricated By Hand-Lay-Up Technique

\begin{tabular}{|c|c|}
\hline Sample & Composition ( Maize husk as filler material ) \\
\hline 1 & Neat Epoxy \\
\hline 2 & Epoxy $+5 \mathrm{wt} \%$ Maize husk filler \\
\hline 3 & Epoxy $+10 \mathrm{wt} \%$ Maize husk filler \\
\hline 4 & Epoxy $+15 \mathrm{wt} \%$ Maize husk filler \\
\hline 5 & Epoxy $+20 \mathrm{wt} \%$ Maize husk filler \\
\hline 6 & Epoxy $+25 \mathrm{wt} \%$ Maize husk filler \\
\hline
\end{tabular}




\section{International Journal of Science and Research (IJSR) \\ ISSN (Online): 2319-7064}

Index Copernicus Value (2013): 6.14 $\mid$ Impact Factor (2014): 5.611

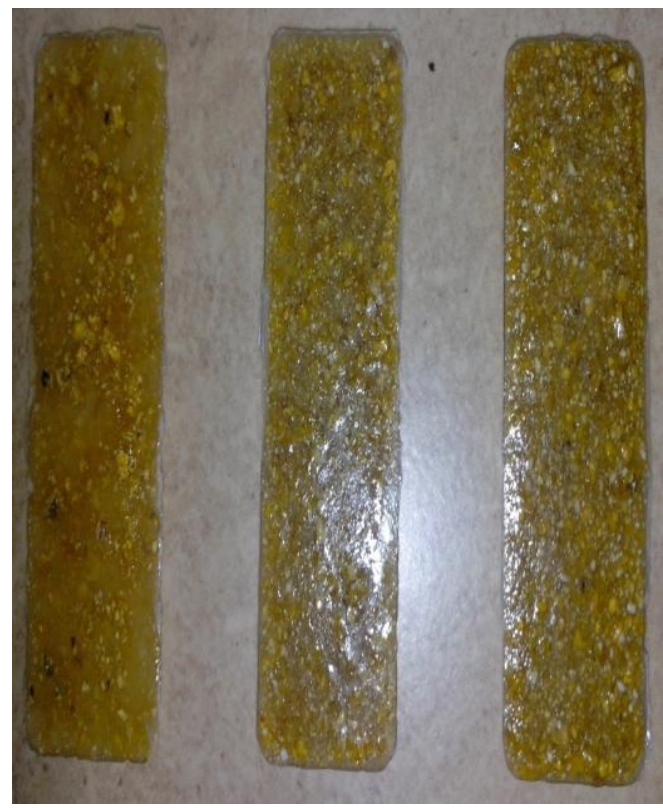

Figure 1: Composites with three different compositions

\section{Results and Discussion}

The physical and thermal properties along with some microstructural features of the prepared maize husk reinforced epoxy composites are presented in this chapter. The interpretation of results and comparison among various composite samples are also presented.

\subsection{Physical Characteristic}

Density is a material property which is of prime importance in several weight sensitive applications. Polymers are well known for their low density. The low densities of polymer composites are found to replace the conventional metals and materials in many engineering applications. Density of a composite depends on the relative weight proportion of matrix and the reinforcing components. The theoretical and experimentally measured densities of epoxy composites reinforced with maize husk, along with the corresponding volume fraction of voids are presented in Table 2 .

Table 2: Density values along with the void fractions of the maize husk filled epoxy composites

\begin{tabular}{|r|c|c|c|c|}
\hline \multicolumn{1}{|c|}{$\begin{array}{c}\text { S. } \\
\text { No. }\end{array}$} & $\begin{array}{c}\text { Filler } \\
\text { Content } \\
(\mathrm{wt} \%)\end{array}$ & $\begin{array}{c}\text { Measured } \\
\text { density } \\
\left(\mathrm{gm} / \mathrm{cm}^{3}\right)\end{array}$ & $\begin{array}{c}\text { Theoretical } \\
\text { density } \\
\left(\mathrm{gm} / \mathrm{cm}^{3}\right)\end{array}$ & $\begin{array}{c}\text { Voids } \\
\text { contents } \\
(\%)\end{array}$ \\
\hline 1 & 0 & 1.1 & 1.1 & ----- \\
\hline 2 & 5 & 0.885 & 0.916 & 3.38 \\
\hline 3 & 10 & 0.736 & 0.785 & 6.24 \\
\hline 4 & 15 & 0.622 & 0.687 & 9.46 \\
\hline 5 & 20 & 0.532 & 0.611 & 12.92 \\
\hline 6 & 25 & 0.459 & 0.551 & 16.69 \\
\hline
\end{tabular}

\subsubsection{Morphological Behavior}

Various properties of particulate filled polymer composites are strongly affected by the compatibility between the matrix and filler phase. The scanning electron microscopy images of the maize husk micro size particles are shown in Figure 2.

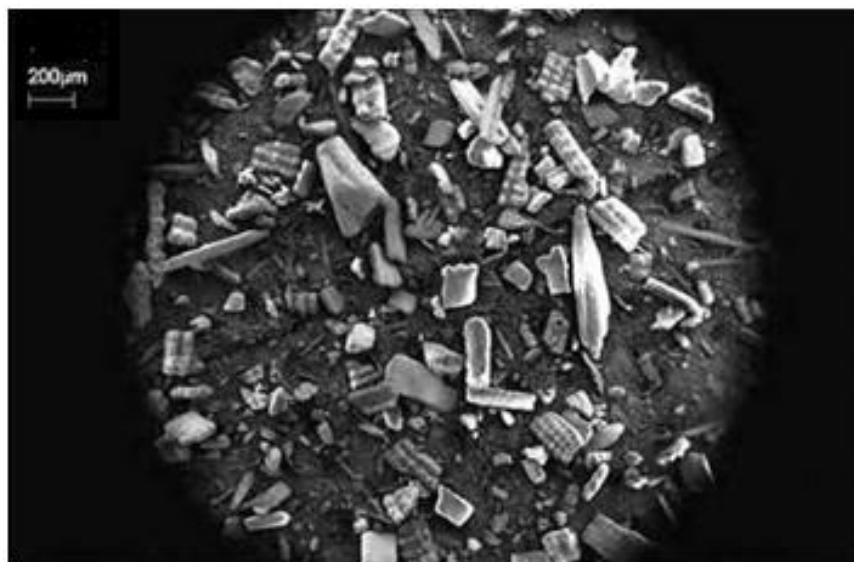

It is clear from the image that the maize husk particles are not of regular shape and similar size which is obvious because the particle used in present investigation are generated by grinding process and no grinding process is as accurate to develop particles of similar shape and size.

\subsection{Thermal Characteristic}

\subsubsection{Effective thermal conductivity}

The effective thermal conductivities of epoxy composites filled with micro-sized maize husk particles with filler weight fraction ranging from $0 \%$ to $25 \%$ are shown in Figure 3. The values of effective thermal conductivities for similar combination are obtained using rules of mixture (ROM) model, Maxwell's correlation, Lewis and Nielsen model are also presented in Figure 4.3. It presents a comparison among the results obtained using various empirical models with regard to the values of effective conductivity obtained experimentally. It can be seen from graph that with increase in content of maize husk in epoxy matrix, the conductivity of the composite body decreases. This results in increase in the insulation capability of the fabricated composite.

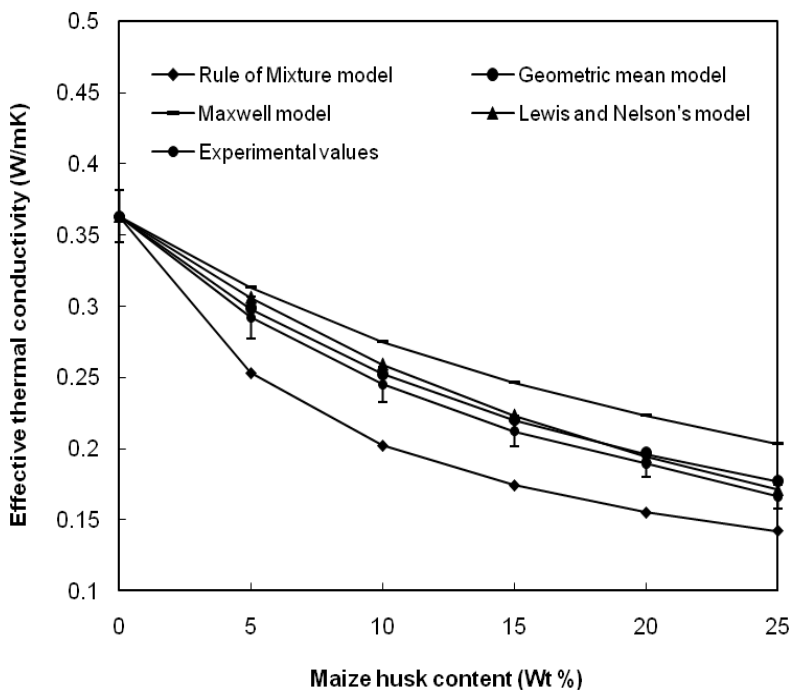

Figure 4.3: Effective thermal conductivity of epoxy composites as a function of filler content

\section{Conclusions}

This present investigation on particulate filled maize husk/ epoxy composites has led to the following conclusions: 


\section{International Journal of Science and Research (IJSR) \\ ISSN (Online): 2319-7064 \\ Index Copernicus Value (2013): 6.14 | Impact Factor (2014): 5.611}

1)Maize husk possesses reinforcing potential to be used as a filler material in epoxy matrix composites

2) Successful fabrication of epoxy matrix composites reinforced with maize husk particles is possible by simple hand-lay-up technique.

3) The density of the fabricated composites decreases with increase in weight fraction and it also possesses low void content; even when it is prepared by hand lay-up technique.

4)By surface morphology it is clear that there is good adhesion between the matrix phase and filler phase and very less gap is visible between them which results in low amount of porosity.

5) With increased thermal insulation, this new class of maize husk filled epoxy composites can be used for applications such as building material, insulated flask, thermal interface material etc

\section{Scope of Future Scope}

1)Exploration of new fillers and polymers for development of materials having low thermal conductivity and low electrical conductivity.

2)Possible use of other agro based fillers, polymeric resins and natural fibers in the development of new hybrid composites.

3) Study on the effect of filler shape and size on thermal properties of the composites.

4)Exploring the possibility of using natural fibers along with different ceramic particulates to fabricate such composites with improved functional properties.

5)Cost analysis of these composites to assess their economic viability in industrial applications.

\section{References}

[1] Gregory SW, Freudenberg KD, Bhimaraj P and Schadler LS (2003). A study on the friction and wear behavior of PTFE filled with alumina nanoparticles. Wear, 254: 573-580.

[2] Jung-il K, Kang PH and Nho YC (2004). Positive temperature coefficient behavior of polymer composites having a high melting temperature. Journal of Applied Polymer Science, 92: 394-401.

[3] Suchtelen VJ (1972). Product properties: a new application of composite materials. Philips Res. Reports, 27: 28-33.

[4] Ranganath S (1997). A Review on Particulate-reinforced titanium matrix composites. Journal of Materials Science, 32: 1-16.

[5] Sawyer WG, Freudenberg KD, Praveen B and Schadler LS (2003). A study on the friction and wear behavior of PTFE filled with alumina nanoparticles. Wear, 254: 573580.

[6] Kim J, Kang PH and Nho YC (2004). Positive temperature coefficient behavior of polymer composites having a high melting temperature. Journal of Applied Polymer Science, 92: 394-401.

[7] Nielsen LE and Landel RF (1994). Mechanical properties of polymers and composites. 2nd ed. New York: Marcel Dekker, pp.557,
[8] Bartczak Z, Argon AS, Cohen RE and Weinberg M (1999). Toughness mechanism in semi-crystalline polymer blends: II. High-density polyethylene toughened with calcium carbonate filler particles. Polymer, 40: 2347-2365,

[9] Young RJ and Beaumont PWR (1977). Failure of brittle polymers by slow crack growth Part 3 Effect of composition upon the fracture of silica particle-filled epoxy resin composites. Journal of Materials Science, 12: 684-692.

[10] Kinloch AJ, Maxwell DL and Young RJ (1985). The fracture of hybrid particulate composites", Journal of Materials Science, 20: 4169-4184.

[11] Nakamura Y, Yamaguchi M, Kitayama A, Okubo M and Matsumoto T (1991). Effect of particle size on fracture toughness of epoxy resin filled with angular-shaped silica. Polymer, 32: 2221-2229.

[12]Nakamura Y., Yamaguchi M., Okubo M. and Matsumoto T., "Effect of particle size on impact properties of epoxy resin filled with angular shaped silica particles", Polymer, Vol. 32(16), pp. 2976-2979, (1991).

[13]Pukanszky B and Voros G (1993). Mechanism of interfacial interactions in particulate filled composite. Composite Interfaces, 1: 411-427.

[14] Nicolais L. and Nicodemo L (1974). The Effect of particles shape on tensile properties of glassy thermoplastic composites. International Journal of Polymeric Materials. 3: 229-243. 